\title{
Zakarpatskiy perlit as component of mineral woven fabric material
}

\author{
O.O. Titova, L.P. Chernyak (ORCID 000-0001-8479-0545), L.A. Nudchenko (ORCID 0000-0001-6519-9864) \\ National Technical University of Ukraine "Igor Sikorsky Kyiv Polytechnic Institute”, av. Peremogy, 37, Bldg. 21, \\ Kyiv, 03056, Ukraine \\ Tel.: +380672985775 \\ E-mail: lpchernyak@ukr.net
}

Article info: received 12.03.2019, revised 15.03.2019, accepted 26.03.2019

Titova, O.O., Chernyak, L.P., Nudchenko, L.A. (2019) Zakarpatskiy perlit as component of mineral woven fabric material 1(42), doi: 10.26909/csl.1.2019.1

Thanks to the peculiarities of the chemical composition and structure, perlite has received application for manufacturing building materials - thermal insulation and ceramic.

Results over of research of the silicate systems with Transcarpathian perlite as raw material for making of mineral astringent material are driven. The features of the chemical-mineralogical composition, phase transformations during burning and astringent properties of material at the use of perlite from Beregovsky deposit in composition initial raw material mixtures are shown.

To determine and optimize raw material stock at the production of mineral binder material of low-temperature roasting type of natural or romanticum, a computer program "RomanCem" was used.

After burning with a maximum temperature of $1100{ }^{\circ} \mathrm{C}$, the test of the binder material from the investigated 3-component mixtures with Transcarpathian perlite is characterized by differences in phase composition and properties.

When using for the manufacture of mineral binder material of low-temperature firing of a gypsum natural or romantic cement 3-component mixtures based on the limestone system - perlit - clay, the content of Transcarpathian perlite is possible from 4 to 22 mass. $\%$.

Key words: perlite, clay, material mixtures, chemical composition and structure.

\section{Закарпатський перліт як компонент мінерального в`яжучого матеріалу}

\author{
О.О. Титова, Л.П. Черняк, Л.А. Нудченко
}

Національний технічний університет Украӥни “Київський політехнічний інститут”, Київ, Украӥна

Наведені результати досліджень силікатних систем із закарпатським перлітом як сировини для виготовлення мінерального в'яжучого матеріалу. Показані особливості хіміко-мінералогічного складу, фазові перетворення при випалі та в’яжучі властивості матеріалу при використанні перліту Берегівського родовища в складі вихідних сировинних сумішей.

\section{Вступ}

Технологія виробництва силікатних матеріалів базується на комплексному використанні сировини різного генезису [1]. При цьому за рахунок варіювання хіміко-мінералогічного складу вихідних сировинних композицій досягається можливість регулювання параметрів структуроутворення та властивостей матеріалів та виробів [2 - 4].

Одним із джерел природної силікатної сировини $\epsilon$ породи вулканічного походження $[5,6]$, серед яких суттєве місце за світовим розповсюдженням і запасам родовищ займає перліт [7].

Завдяки особливостям хімічного складу та структури, перліт отримав застосування для виготовлення будівельних матеріалів - теплоізоляційних і керамічних [8 - 11].

В той же час, подальше підвищення ефективності роботи діючих кар'єрів потребує розширення напрямків практичного використання перліту. Одним 3 таких перспективних напрямків може стати масоємне виробництво мінеральних в'яжучих матеріалів, що стало метою поданої роботи. 


\section{Матеріали та методи дослідження}

В даній роботі було досліджено суміші на основі силікатної системи вапняк - глина - перліт. Відзнакою такої системи є комплексне застосування природної сировини різного генезису:

- вапняк Дубовецького родовища Івано-Франківської області, що промислово використовується ПАТ «Івано-Франківськцемент»;

- глину Кривинського родовища Рівненської області, що промислово використовується ПАТ «Волинь-цемент»;

- перліт Берегівського родовища Закарпатської області, що розробляється компанією «Перліт груп» (Україна).

Хімічний склад досліджуваної проби перліту відзначається високим вмістом $\mathrm{SiO}_{2}$ при кількісному співвідношенні $\mathrm{SiO}_{2}: \mathrm{Al}_{2} \mathrm{O}_{3}=6: 1$ та лужних оксидів типу $\mathrm{R}_{2} \mathrm{O}=8,09$ мас. \% (табл. 1 ).

Вапняк характеризується кількісним співвідношенням $\mathrm{CaO}: \mathrm{SiO}_{2}=16: 9$, відносно меншим вміс- том $\mathrm{Fe}_{2} \mathrm{O}_{3}$, проба кривинської глини - кількісному співвідношенні $\mathrm{SiO}_{2}: \mathrm{Al}_{2} \mathrm{O}_{3}=4: 1$.

Рентгенофазовий аналіз порошкових препаратів досліджуваної сировини, проведений з застосуванням дифрактометру ДРОН - 3М, дозволив виявити наступні особливості мінералогічного складу проб: перліт характеризується розвиненою склофазою із кристалічними включеннями кварцу та польового шпату (рис. 1), вапняк відрізняється превалюючим вмістом кальциту, кривинські глини відносяться до групи полімінеральних з підвищеним вмістом монтморилоніту, кварцу та польових шпатів.

Відповідно до сучасної технології в'яжучих сировинні суміші визначеного складу готували шляхом дозування компонентів по масі, змішування та гомогенізації при двохстадійному помелі у кульовому млині, випалу і помелу кінцевого продукту.

Виготовлені проби сировинних сумішей випалювали в печі протягом 15 годин в інтервалі максимальних температур $1050-1150{ }^{\circ} \mathrm{C}$ з витримкою при максимумі 1,5 год.

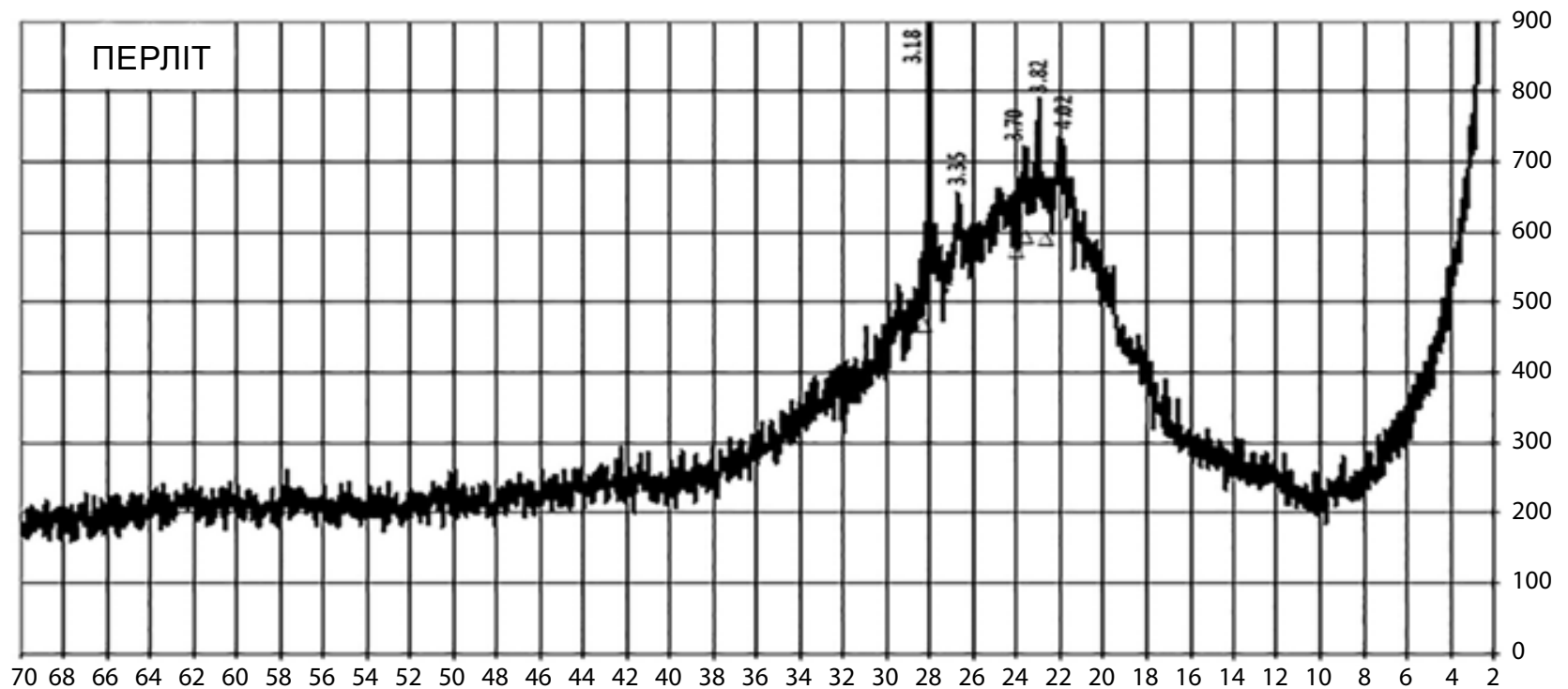

Рис. 1. Дифрактограма проби закарпатського перліту: v-кварц, $\Delta$-польовий шпат

Таблиця 1.

Хімічний склад сировини

\begin{tabular}{|c|c|c|c|c|c|c|c|c|c|c|}
\hline \multirow{2}{*}{$\begin{array}{l}\text { Назва } \\
\text { проби }\end{array}$} & \multicolumn{10}{|c|}{ Вміст оксидів, мас. \% } \\
\hline & $\mathrm{SiO}_{2}$ & $\mathrm{Al}_{2} \mathrm{O}_{3}$ & $\mathrm{Fe}_{2} \mathrm{O}_{3}$ & $\mathrm{TiO}_{2}$ & $\mathrm{CaO}$ & $\mathrm{MgO}$ & $\mathrm{SO}_{3}$ & $\mathrm{Na}_{2} \mathrm{O}$ & $\mathrm{K}_{2} \mathrm{O}$ & в.П.П \\
\hline перліт & 72,08 & 12,92 & 1,50 & 0,90 & 0,88 & 0,63 & - & 3,76 & 4,33 & 3,0 \\
\hline вапняк & 3,13 & 0,06 & 1,05 & - & 52,82 & 0,52 & 0,10 & - & - & 42,32 \\
\hline кривинська & 60,96 & 15,66 & 5,57 & 0,79 & 3,33 & 2,04 & 0,16 & 0,30 & 2,70 & 8,48 \\
\hline
\end{tabular}


Всі зразки дослідних сумішей, показники яких порівнювали, сушили та випалювали разом, аби виключити можливість різниці в ступені термічної обробки.

\section{Результати та їх обговорення}

Для визначення та оптимізації вихідних сировинних складів при виготовленні мінерального в'яжучого матеріалу низькотемпературного випалу типу натурального або романцементу було використано комп’ютерну програму «РоманЦем» [12].

Результати комп'ютерних розрахунків показали, що при використанні сумішей на основі системи вапняк - глина - перліт можливий вміст перліту становить 10 - 23 мас. \% при гідравлічному модулі $\mathrm{HM}=1.10$ та 4 - 13 мас. \% при гідравлічному модулі $\mathrm{HM}=1.70$ (рис. 2).

При використанні системи з глиною в інтервалі концентрацій перліту $\mathrm{Cp}=4$ - 9 мас. \% при $\mathrm{HM}=1,1$ та $\mathrm{HM}=1,7$ в'яжучий матеріал характеризується числами кремнеземного ( $\mathrm{n}=3,1-3,3)$ та глиноземного ( $\mathrm{p}=1,9$ - 2,3) модулів, що відповідають рекомендованим показникам для цементу.
Фазовий склад $і$ властивості в 'яжучого матеріaлy. Для дослідження особливостей структуроутворення та властивостей мінерального в'яжучого на основі системи вапняк - перліт - глина кривинська було обрано проби 40в, 41в, склад яких після випалу має при гідравлічному модулі $\mathrm{HM}=1,1$ забезпечити значення кремнеземного модулю (n) 3,1 і 3,5 та глиноземного (р) 2,2 і 2,5 (табл. 2).

Таблиця 2.

Склад сировинних сумішей

\begin{tabular}{|c|c|c|c|}
\hline \multirow{2}{*}{$\begin{array}{c}\text { Код } \\
\text { суміші }\end{array}$} & \multicolumn{3}{|c|}{ Вміст компонентів, мас. \% } \\
\cline { 2 - 4 } & вапняк & перліт & глина \\
\hline 40в & 65,7 & 4,3 & 30,0 \\
\hline 41в & 66,5 & 13,5 & 20,0 \\
\hline 42в & 76,5 & 8,5 & 15,0 \\
\hline
\end{tabular}

Проба 42в при гідравлічному модулі $\mathrm{HM}=1,7$ має забезпечити значення $\mathrm{n}=3,4 \mathrm{i} \mathrm{p}=2,1$.
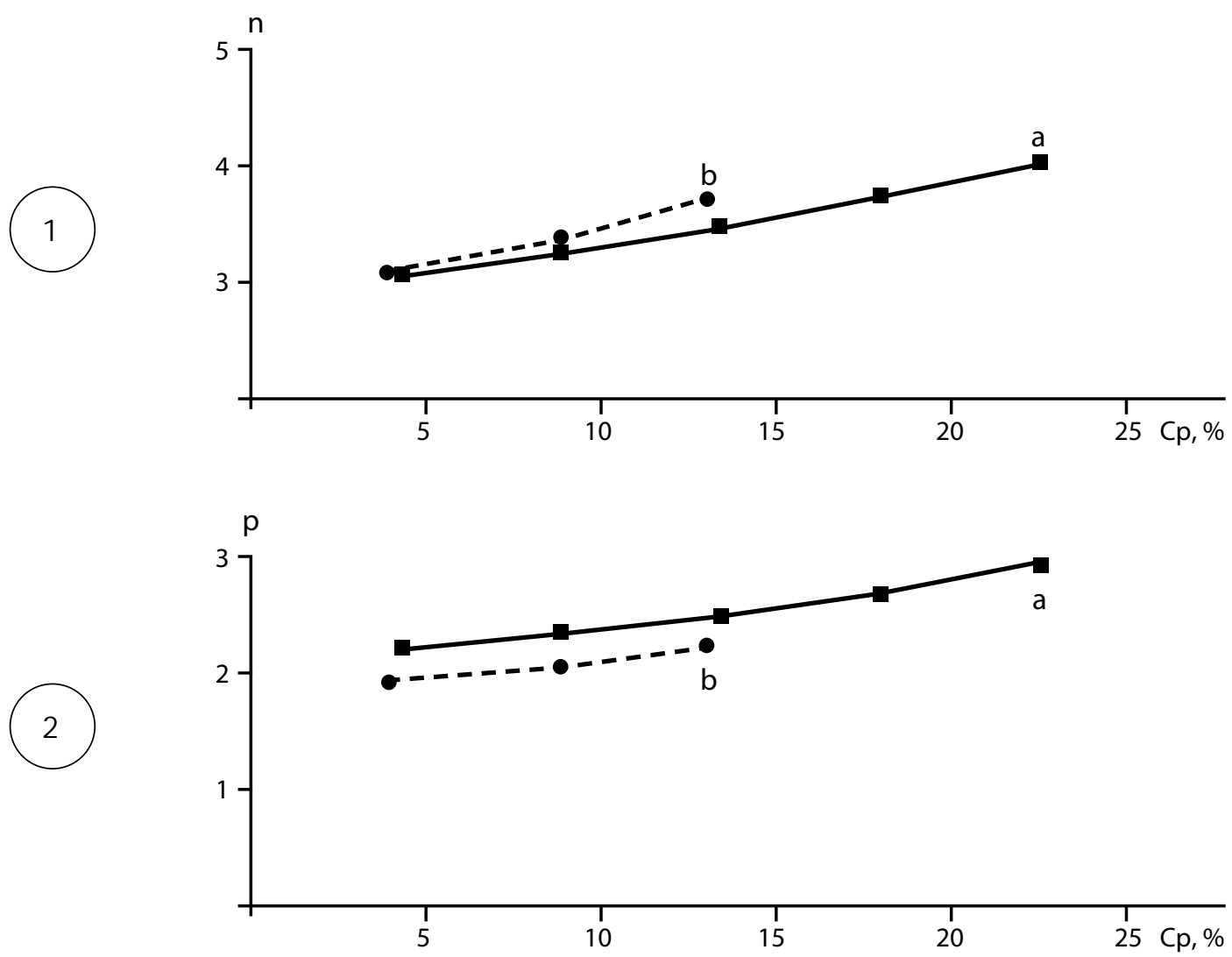

Рис. 2. Залежність кремнеземного n (1) та глиноземного р (2) модулів від концентрації перліту (Сp) в системі вапняк - глина - перліт при $\mathrm{HM}=1,1$ (a) i $\mathrm{HM}=1,7$ (b) 
Кількісному співвідношенню компонентів відповідають відмінності хіміко-мінералогічного складу 3-компонентних сумішей.

При однаковій кількості вапняку проби 40в, 41в близькі за хімічним складом (табл. 3), разом $з$ тим, при більшому кількісному співвідношенні перліту та глини (1:1,5 проти 1:7) проба 41в відрізняється від 40в деяким збільшенням кількісних співвідношень $\mathrm{CaO}: \mathrm{Al}_{2} \mathrm{O}_{3}(6,9$ проти 6,5).

Таблиця 3.

Хімічний склад сировинних сумішей

\begin{tabular}{|c|c|c|c|c|c|}
\hline \multirow{2}{*}{$\begin{array}{c}\text { Код } \\
\text { суміші }\end{array}$} & \multicolumn{5}{|c|}{ Вміст оксидів, мас. \% } \\
\cline { 2 - 6 } & $\mathrm{CaO}$ & $\mathrm{SiO}_{2}$ & $\mathrm{Al}_{2} \mathrm{O}_{3}$ & $\mathrm{Fe}_{2} \mathrm{O}_{3}$ & $\mathrm{MgO}$ \\
\hline 40 в & 35,77 & 24,49 & 5,53 & 2,50 & 1,01 \\
\hline 41 в & 35,98 & 25,41 & 5,21 & 2,08 & 0,86 \\
\hline 42в & 41,00 & 18,62 & 3,70 & 1,81 & 0,78 \\
\hline
\end{tabular}

Проба 42в при суттєво більшому вмісті вапняку та кількісному співвідношенні перліту та глини 1:1,8 відрізняється від 40в, 41в суттєвим збільшенням кількісних співвідношень $\mathrm{CaO}: \mathrm{SiO}_{2}$ (2,2 проти 1,4), $\mathrm{CaO}: \mathrm{Al}_{2} \mathrm{O}_{3}(11,1$ проти 6,5 - 6,9).

Після випалу 3 максимальною температурою $1100^{\circ} \mathrm{C}$ проби в'яжучого матеріалу з досліджуваних 3-компонентних сумішей із закарпатським перлітом характеризуються відмінностями фазового складу та властивостей.

Рентгенофазовий аналіз проб показав, що при приблизно однаковому якісному складі вони мають певні відмінності в кількісному співвідношенні окремих фаз (рис. 3 - 5).

Виявлено, що при однаковому вмісті вапняку із збільшенням вмісту перліту (13,5 проти 4,3 мас. \%) та його кількісного співвідношення із глиною $(1: 1,5$ проти $1: 7)$ проба із суміші 41в відрізняється від 40в:

- щодо кристалічних фаз силікатів кальцію - інтенсифікацією утворення $\mathrm{C}_{2} \mathrm{~S}(2,61 \AA ̊)$ при меншому вмісті воластоніту CS (2,97 ̊̊);

- щодо кристалічних фаз алюмінатів кальцію - інтенсифікацією утворення майєніту $\mathrm{C}_{12} \mathrm{~A}_{7}(4,90 \AA)$ при меншому вмісті СА $(4,66 \AA)$ та $\mathrm{C}_{3} \mathrm{~A}(2,70 \AA ̊)$;

- щодо кристалічних фаз алюмосилікатів кальцію меншим утворенням геленіту $\mathrm{C}_{2} \mathrm{AS}(2,86 \AA)$;

- зменшенням вмісту вільного СаO $(2,38 \AA$ А).

При суттєво більшому вмісті вапняку та кількісному співвідношенні перліту та глини 1:1,8 проба 42в відрізняється від 41в:

- щодо кристалічних фаз силікатів кальцію - суттєво меншим утворенням воластоніту CS $(2,97 \AA)$ при незначно більшому розвитку $\mathrm{C}_{2} \mathrm{~S}(2,61 \AA ̊)$;

- щодо кристалічних фаз алюмінатів кальцію - інтенсифікацією утворення майєніту $\mathrm{C}_{12} \mathrm{~A}_{7}(4,90 \AA)$ та $\mathrm{C}_{3} \mathrm{~A}(2,70 \AA)$ при меншому вмісті СА $(4,66 \AA)$;

- щодо кристалічних фаз алюмосилікатів кальцію - меншим утворенням геленіту $\mathrm{C}_{2} \mathrm{AS}(2,86 \AA)$;

- зменшенням вмісту кристалічного кварцу $(3,35 \AA)$ та вільного $\mathrm{CaO}(2,38 \AA)$.

Згідно класифікації ДСТУ Б В.27-91-99 після випалу на $1100{ }^{\circ} \mathrm{C}$ за швидкістю тужавлення досліджувані проби в'яжучого на основі системи вапняк - глина - перліт відносяться до групи швидкотужавіючих (термін початку від 15 до 45 хв.), характерними представниками якої вважаються ангідритовий та глиноземистий цементи (табл. 4).

Таблиця 4.

Властивості в'яжучого матеріалу

\begin{tabular}{|c|c|c|c|c|}
\hline \multirow{2}{*}{\multicolumn{2}{|c|}{ Показники }} & \multicolumn{3}{|c|}{ Код проби } \\
\hline & & $40 \mathrm{~B}$ & $41 \mathrm{~B}$ & $42 \mathrm{~B}$ \\
\hline \multicolumn{2}{|c|}{ Тонкість помелу, залишок на ситі 008, мас. \% } & 7 & 8 & 8 \\
\hline \multirow{2}{*}{ Терміни тужавлення, хв. } & початок & 10 & 15 & 25 \\
\hline & кінець & 25 & 45 & 70 \\
\hline \multicolumn{2}{|c|}{ Міцність на стиск через 28 діб, МПа } & 21 & 23 & 23 \\
\hline
\end{tabular}




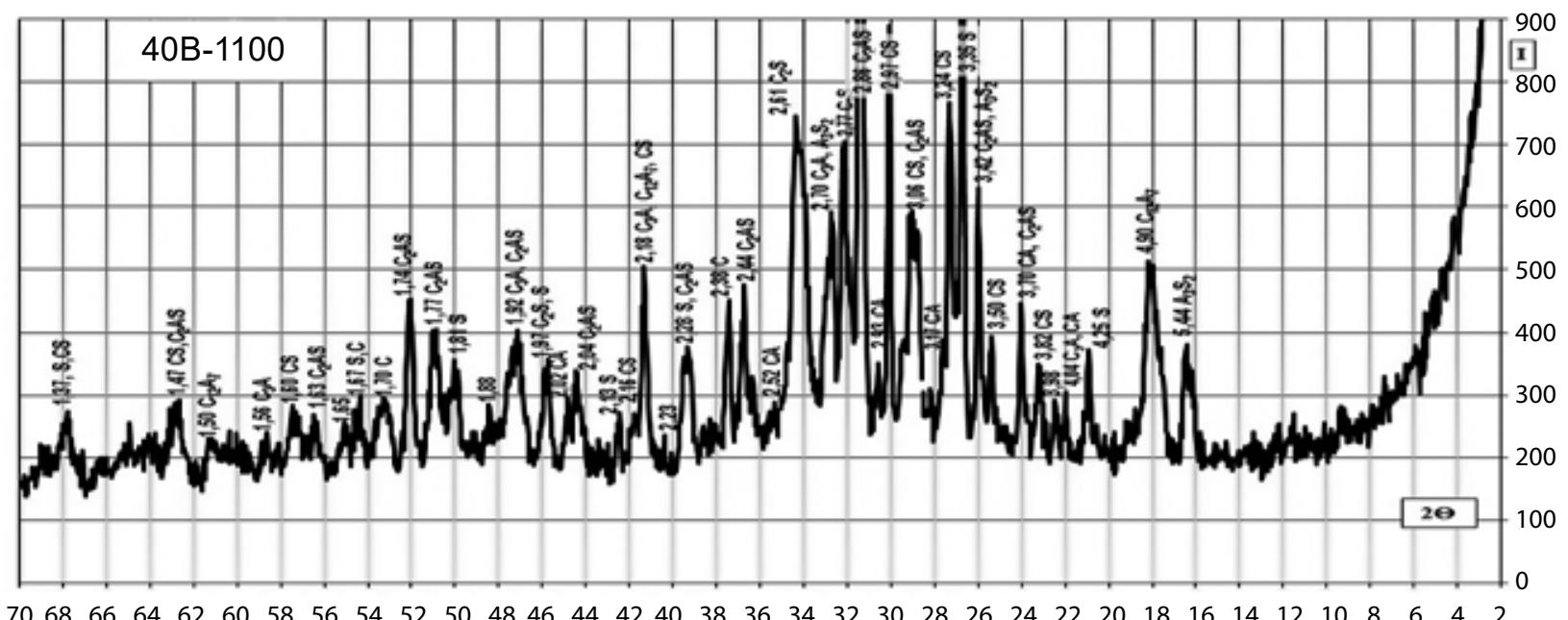

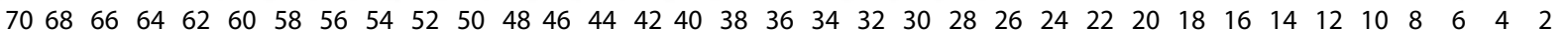

Рис. 3. Дифрактограма проби в’яжучого 40в після випалу на 1100 C

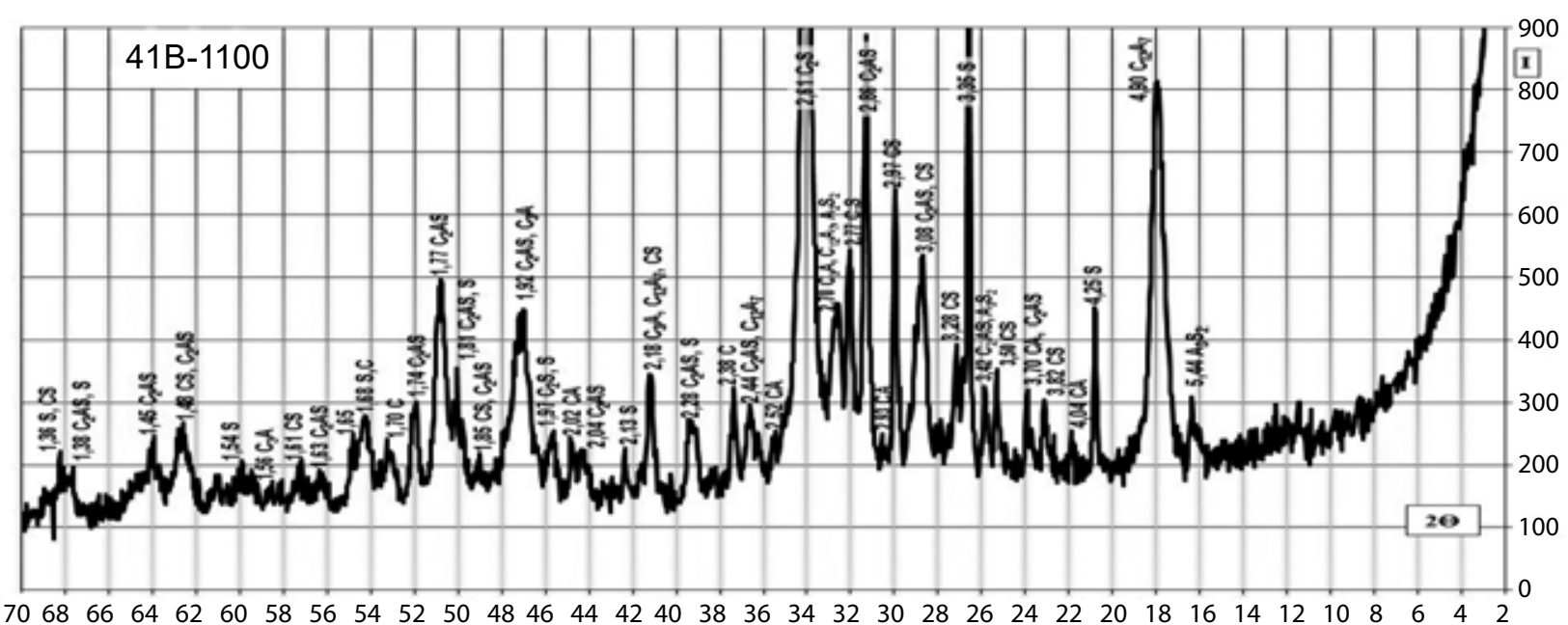

Рис. 4. Дифрактограма проби в’яжучого 41 в після випалу на $1100{ }^{\circ} \mathrm{C}$

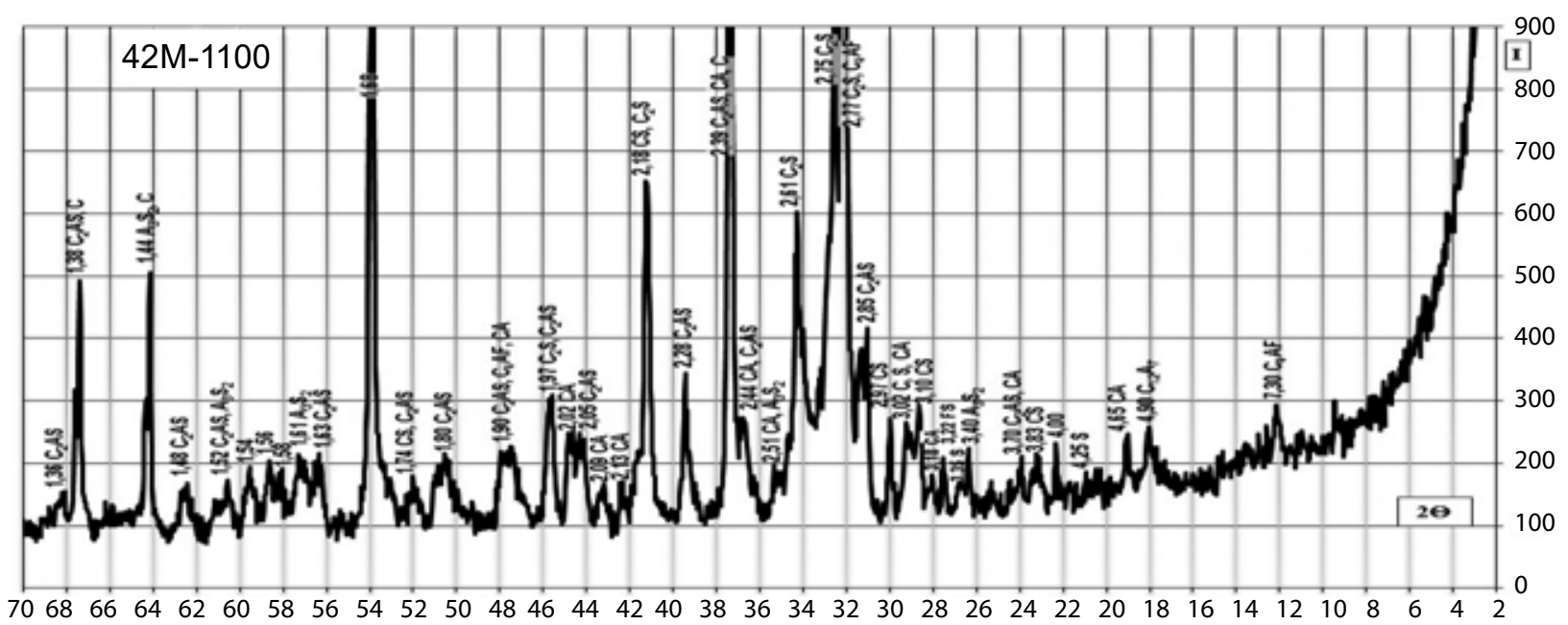

Рис. 5. Дифрактограма проби в’яжучого 42в після випалу на $1100^{\circ} \mathrm{C}$ 


\section{Висновки}

1. При використанні для виготовлення мінерального в'яжучого матеріалу низькотемпературного випалу типу натурального або романцементу 3-компонентних сумішей на основі системи вапняк - перліт - глина можливий вміст закарпатського перліту становить від 4 до 22 мас. \%. При цьому в інтервалі концентрацій перліту $\mathrm{Cp}=4$ - 9 мас. \% в'яжучий матеріал характеризується значеннями кремнеземного $(\mathrm{n}=3,1-3,3)$ та глиноземного $(\mathrm{p}=1,9$ - 2,3) модулів, що відповідають рекомендованим показникам для цементу.

2. За результатами тестувань досліджуваних матеріалів після випалу 3 максимальною температурою $1100{ }^{\circ} \mathrm{C}$ встановлено відмінності їх в'яжучих властивостей. Згідно класифікації ДСТУ Б В.27-91-99 за швидкістю тужавлення досліджувані проби в'яжучого на основі системи вапняк - глина - перліт відносяться до групи швидкотужавіючих (термін початку від 15 до 45 хв.), характерними представниками якої вважаються ангідритовий та глиноземистий цементи. При цьому швидкість тужавлення залежить від кількісного співвідношення компонентів сировинної суміші, сповільнюючись при зміні кількісного співвідношення перліт : глина від 1:7 до 1:1,5 - 1,8.

3. За структурними ознаками після випалу з максимальною температурою $1100^{\circ} \mathrm{C}$ досліджувані проби в'яжучого матеріалу характеризуються однаковим якісним фазовим складом, проте мають відмінності у ступені розвитку та кількісному співвідношенні окремих фаз: при зміні кількісного співвідношення перліт : глина від 1:7 до 1:1,5 - 1,8 спостерігаються інтенсифікацією утворення $\mathrm{C}_{2} \mathrm{~S}, \mathrm{C}_{12} \mathrm{~A}_{7}$ при зменшенні вмісту зменшенням вмісту кристалічного кварцу, вільного $\mathrm{CaO}, \mathrm{CA}$ i $\mathrm{C}_{2} \mathrm{AS}$.

\section{References}

1. Комплексное развитие сырьевой базы промышленности строительных материалов / Удачкин И.Б., Пащенко А.А., Черняк Л.П., Захарченко П.В., Семидидько А.С., Мясникова Е.А. - К.: Будівельник. - 1988. - 104 с.
2. Будников, П.П., Гинстлинг, А.М. Реакции в смесях твердых веществ. - М.: Стройиздат. - 1971. $488 \mathrm{c}$.

3. Черняк, Л.П. Критерії вибору сировини для сучасного виробництва будівельної кераміки // Строительные материалы и изделия. - 2003. - №1. C. 2 - 4. - №2. - С. 6 - 8 .

4. Черняк, Л.П. Особливості структуроутворення дисперсних систем у технології портландцементу // Технологический аудит и резервы производства. 2013. - Т.6. - № 5(14). - С. 8 - 10.

5. Козырев, В.В. Вулканические породы как сырье для керамической промышленности / В.В. Козырев, Ю.С. Спешнев, Л.В. Ерохина // - М.: ВНИИЭСМ. 1975. $-45 \mathrm{c}$.

6. Гуменюк, Е.Л. Структурообразование и свойства некоторых пород вулканического происхождения / Е.Л. Гуменюк, Р.М. Зайонц, Л.П. Черняк // Исследования в области технологии производства новых видов керамических изделий. - М.: Стройиздат. 1980. - C. 109 - 117.

7. Minerals Yearbook, volume III, Area Reports-International-Europe and Central Eurasia. - U.S. Geological Survey. -2018.

8. Singh, M., Garg, M. Perlite-based building materials - a review of current applications / Manjit Singh, Mridul Garg // Construction and Building Materials. 1991. - No. 5(2). - P. 75 - 81.

9. Taspinar, B., Nuranay. Use of perlite in wall tile production / American Ceramic Society Bulletin. - 1999. - No. 78(6). - P. 86 - 87.

10. Алексеева, Л.В. Опыт применения вспученного перлита в строительстве / Л.В. Алексеева, С.Ю. Нациевский // Строительные материалы и изделия. - 2013. - № 5 - 6. - C. 62 - 64.

11. Yesilyurt, Er. Investigation of Availability of Raw Perlite in Refractory Building Material Production / Ergün Yesilyurt, Osman Simsek, Ahmet Bilgil // Periodicals of Engineering and Natural Scinces. - 2018. Vol. 6. - No. 1. - P. 41 - 51.

12. Свідерський, В.А. Програмне забезпечення технології низькотемпературних вяжучих матеріалів / В.А. Свідерський, Л.П. Черняк, О.В. Сангінова, Н.О. Дорогань, М.Ю. Цибенко // Строительные материалы и изделия. - 2017. - №1 - 2 (93). - С. 22 - 24 